\title{
PENYULUHAN KESEHATAN TENTANG PENGGUNAAN ALAT PELINDUNG DIRI PADA MAHASISWA PROFESI NERS SEBAGAI UPAYA PENCEGAHAN COVID-19
}

\author{
Fitri Dian Kurniati ${ }^{1 *}$, Viantika Kusumasari², Ani Mashunatul Mahmudah ${ }^{3}$, \\ Muskhab Eko Riyadi ${ }^{4}$ \\ ${ }^{1-4}$ Stikes Surya Global Yogyakarta \\ Email Korespondensi: fitridian_kurniati@yahoo.co.id
}

Disubmit: 03 November 2021 Diterima: 11 Desember $2021 \quad$ Diterbitkan: 02 Januari 2022 DOI: https://doi.org/10.33024/jkpm.v1i1.5415

\begin{abstract}
ABSTRAK
Pandemi covid-19 telah mengubah sistem pembelajaran pada program studi pendidikan profesi ners di STIKes Surya Global Yogyakarta. Semua kegiatan praktik di lapangan dilakukan secara daring sampai diberlakukannya new normal oleh pemerintah. New normal mengharuskan mahasiswa menerapkan protokol kesehatan dengan ketat pada saat kembali praktik di rumah sakit guna mencegah terjadinya penularan corona virus. Upaya preventif yang dapat dilakukan untuk memutus penularan covid-19 adalah dengan menggunakan Alat Pelindung Diri (APD) dengan tepat. Oleh karena itu perlu dilakukan upaya untuk meningkatkan pengetahuan dan meningkatkan kemampuan mahasiswa profesi ners dalam menggunakan APD melalui penyuluhan kesehatan tentang penggunaan APD. Penyuluhan kesehatan tentang penggunaan APD dilakukan dengan metode ceramah dan demonstrasi. Sebelum penyuluhan kesehatan dilakukan pretest dan pada akhir kegiatan dilakukan posttest. Nilai rata-rata sebelum mendapatkan penyuluhan kesehatan sebesar 11,6 dan sesudah mendapatkan penyuluhan kesehatan yaitu 15,77. Hasil dari kegiatan ini menunjukkan bahwa terdapat peningkatan pengetahuan pada mahasiswa profesi ners tentang pengggunaan APD.
\end{abstract}

Kata Kunci : Penyuluhan Kesehatan, Alat Pelindung Diri, Covid-19

\begin{abstract}
The COVID-19 pandemic has changed the learning system in the nursing professional education study program at STIKes Surya Global Yogyakarta. All practical activities in the field are carried out online until the new normal is enforced by the government. New normal requires students to strictly implement health protocols when returning to practice in hospitals to prevent transmission of the corona virus. Preventive measures that can be taken to stop the transmission of COVID-19 are to use Personal Protective Equipment (PPE) appropriately. Therefore, it is necessary to make efforts to increase knowledge and improve the ability of nursing professional students in using PPE through health education about the use of PPE. Health education on the use of PPE is carried out using lecture and demonstration methods. Before the health education a pretest was conducted and at the end of the activity a posttest was conducted. The average value before receiving health education was 11.6 and
\end{abstract}


after receiving health education was 15.77 . The results of this activity indicate that there is an increase in knowledge among nursing professional students about the use of PPE.

Keywords: Health Education, Personal Protective Equipment

\section{PENDAHULUAN}

Corona Virus Disease-19 (covid-19) merupakan penyakit menular yang disebabkan oleh virus severe acute respiratory syndrome coronavirus-2 (SARSCoV-2). Wabah COVID-19 pertama kali dideteksi di Kota Wuhan, Provinsi Hubei, Tiongkok pada bulan Desember 2019, dan ditetapkan sebagai pandemi oleh World Health Organization (WHO) pada tanggal 11 Maret 2020 (WHO, 2020).

Rekomendasi standar untuk mencegah penyebaran infeksi covid-19 adalah melalui cuci tangan secara teratur menggunakan sabun dan air bersih, menerapkan etika batuk dan bersin, menghindari kontak secara langsung dengan ternak dan hewan liar serta menghindari kontak dekat dengan siapapun yang menunjukkan gejala penyakit pernapasan seperti batuk dan bersin (Kemenkes RI, 2020). Orang yang paling berisiko tertular penyakit ini adalah orang yang kontak erat dengan pasien covid-19 termasuk yang merawat pasien covid-19. Perawat merupakan salah satu tenaga medis sebagai garda depan dalam penanggulangan covid-19. Berdasarkan data dari Persatuan Perawat Nasional Indonesia (PPNI) diperoleh data bahwa lebih dari 3.300 perawat yang terinfeksi covid-19 dan sejumlah 118 meninggal (PPNI, 2020).

Salah satu upaya yang dapat dilakukan untuk memutus penularan covid-19 adalah dengan menggunakan Alat Pelindung Diri (APD). Berdasarkan Permenaker nomor 8 tahun 2010, APD adalah suatu alat yang mempunyai kemampuan untuk melindungi seseorang yang fungsinya mengisolasi sebagian atau seluruh tubuh dari potensi bahaya. Tipe APD yang wajib digunakan oleh perawat di fasilitas kesehatan yaitu masker, gaun, sarung tangan, pelindung mata (kacamata goggle), dan pelindung wajah (Kemenkes, 2020). Ketersediaan APD terbukti memiliki pengaruh terhadap kecemasan petugas kesehatan dalam upaya pencegahan covid-19 (Fadli dkk, 2020). Kelangkaan APD dan kurangnya pengetahuan terkait penggunaan APD dapat meningkatkan risiko tenaga kesahatan terpapar covid-19 (Gupta \& Kakkar, 2020).

Nurbeti, dkk (2021) menyebutkan bahwa kepatuhan penggunaan APD bagi tenaga kesehatan sesuai standar rasional dapat dipengaruhi oleh beberapa faktor yaitu tingkat pengetahuan, ketersediaan APD, ketakutan, lama pengalaman kerja, dukungan lingkungan atau rekan kerja, dan tanggung jawab personal. Tingkat pengetahuan yang kurang bisa menyebabkan kejadian injury perawat akibat penggunaan APD jangka panjang dalam pelayanan covid-19 (Urrahman dkk, 2021). Pemerintah dan organisasi profesi tenaga kesehatan perlu meningkatkan pengetahuan dan keterampilan penggunaan APD bagi petugas kesehatan (Guan et al., 2020). Sharma, et al (2020) mengemukakan bahwa penggunaan APD dan pelatihan terkait pencegahan infeksi berkaitan dengan penurunan risiko terinfeksi covid-19.

Berdasarkan pemaparan di atas, maka perlu dilakukan penyuluhan kesehatan untuk mengoptimalkan penggunaan APD sebagai upaya pencegahan penularan virus covid-19 khususnya pada saat mahasiswa profesi ners melakukan praktik profesi ners di rumah sakit. 


\section{MASALAH}

Alasan memilih tempat kegiatan karena kegitan proses belajar mengajar di Stikes Surya Global Yogyakarta khususnya pada program studi pendidikan profesi ners pada masa pandemi covid-19 dilakukan secara daring pada bulan Maret 2020 dan pada saat ini sudah kembali normal semua kegiatan praktik pembelajaran mahasiswa profesi ners mulai praktik di rumah sakit. Mahasiswa profesi ners sangat membutuhkan bekal terkait dengan penggunaan APD yang baik selama praktik di rumah sakit. Tujuan pelaksanaan kegiatan ini adalah untuk meningkatkan pengetahuan dan meningkatkan kemampuan mahasiswa profesi ners dalam menggunakan APD secara benar dan tepat pada saat pelaksanaan praktik profesi ners di rumah sakit sebagai upaya pencegahan penularan covid19.

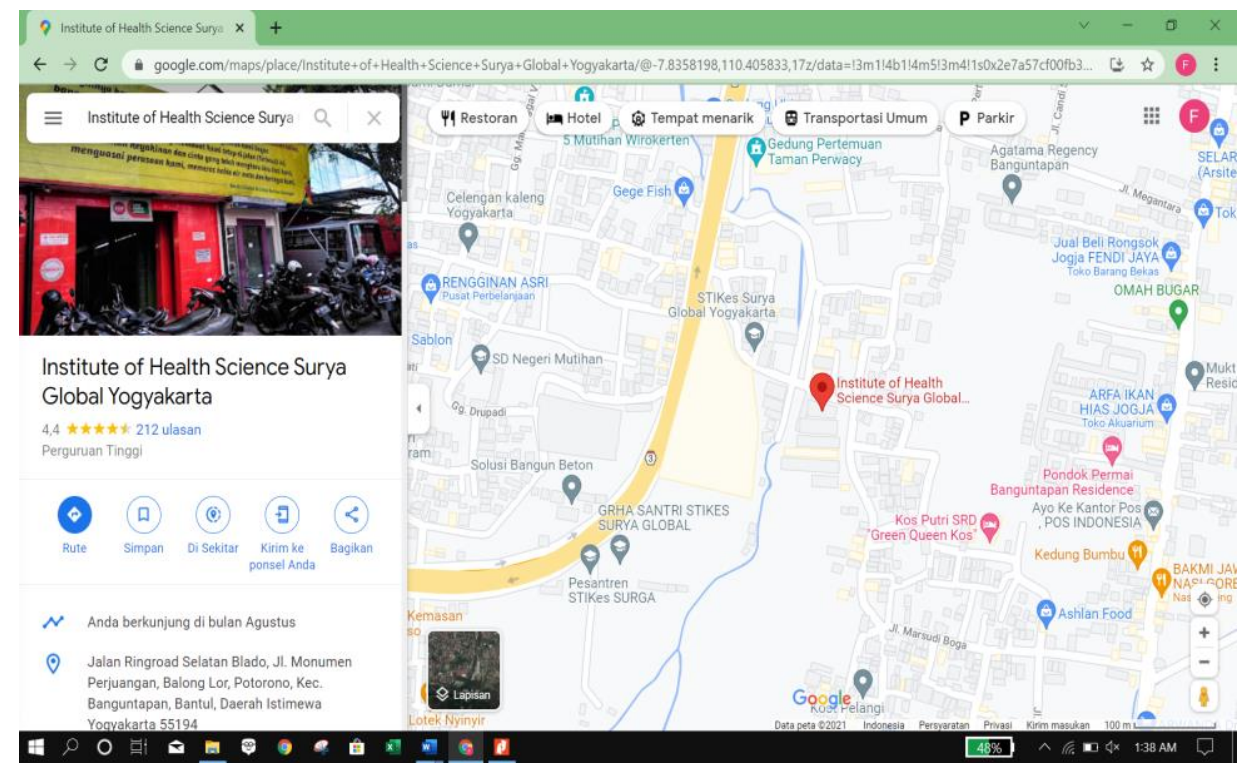

Gambar 2.1 Peta Lokasi Kegiatan Pengabdian Kepada Masyarakat

\section{METODE}

\section{a. Tahap Persiapan}

Tahap persiapan dari kegiatan ini yaitu diawali dengan melakukan kontrak waktu dengan pihak program studi pendidikan profesi ners. Setelah itu mempersiapkan proposal dan surat izin pelaksanaan kegiatan pada tahap ini. Tahap selanjutnya adalah mempersiapkan materi dan bahan-bahan yang dibutuhkan pada kegiatan berupa materi penyuluhan tentang penggunaan APD dan logistik APD terdiri dari masker, sarung tangan, dan gaun. Pengabdi juga melakukan koordinasi dengan bagian pengajaran Stikes Surya Global Yogyakarta terkait dengan peminjaman ruangan yang digunakan untuk kegiatan penyuluhan kesehatan.

\section{b. Tahap pelaksanaan}

Pada awal tahap ini dilakukan pretest kepada peserta penggunaan APD. Pretest dilakukan sebelum pemaparan materi yang berfungsi untuk mengetahui sejauh mana pengetahuan peserta terhadap materi yang akan diberikan. Tahap selanjutnya yaitu pemaparan materi tentang penggunaan APD. Setelah itu peserta mempraktikkan atau mendemonstrasikan penggunaan APD secara tepat. Pada tahap demonstrasi ini para peserta dibagi menjadi enam kelompok, masingmasing kelompok terdiri dari lima mahasiswa. Pada akhir sesi kegiatan penyuluhan dilakukan posttest. 


\section{c. Evaluasi}

i. Struktur

Peserta kegiatan adalah seluruh mahasiswa profesi ners angkatan XXVI yang berjumlah 53 mahasiswa. Peserta terlihat sangat aktif dan antusias dalam mengikuti kegiatan ini.

ii. Proses

Tempat pelaksanaan kegiatan ini yaitu di ruang GSP 2 Stikes Surya Global Yogyakarta. Jumlah peserta dibagi menjadi dua sesi, jadi masing-masing sesi terdiri dari 29 mahasiswa. Sesi pertama dilaksanakan pada pukul $08.00-10.00$ WIB dan sesi kedua dilaksanakan pada pukul 10.30 - 12.30 WIB. Proses kegiatan berjalan sesuai dengan jadwal yang sudah direncanakan.

\section{HASIL DAN PEMBAHASAN}

Kegiatan penyuluhan kesehatan tentang penggunaan APD dilaksanakan pada hari Selasa, tanggal 16 Februari 2021. Metode yang digunakan dalam penyuluhan kesehatan yaitu ceramah, diskusi, dan demonstrasi. Sebelum penyuluhan dilakukan pretest dan setelah penyuluhan dilakukan posttest. Pretest dan posttest menggunakan soal-soal yang sama baik jenis maupun jumlahnya. Tujuannya adalah untuk mengevaluasi tingkat pengetahuan mahasiswa profesi ners sebelum dan sesudah dilakukan penyuluhan kesehatan. Hasil pretest dan posttest pelaksanaan penyuluhan kesehatan adalah sebagai berikut:

a. Pretest Sebelum Pelaksanaan Penyuluhan Kesehatan

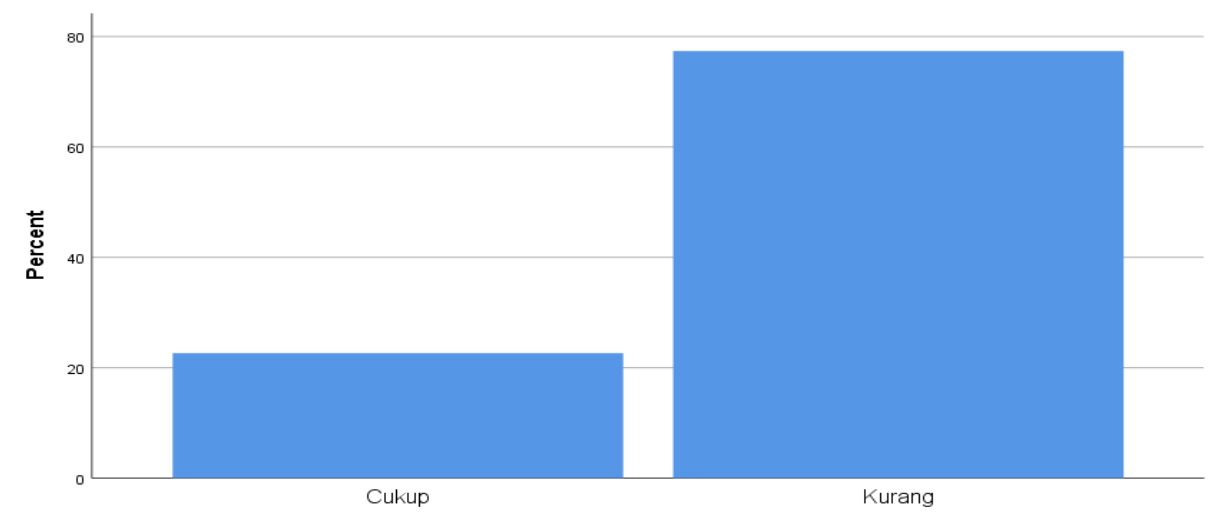

Diagram 1 Tingkat Pengetahuan Mahasiswa Profesi Ners Sebelum Penyuluhan Kesehatan Tentang APD

Tingkat pengetahuan responden sebelum dilakukan pendidikan kesehatan tentang penggunaan APD mayoritas dalam kategori kurang yaitu sebesar $77,4 \%$ (41 responden) dan 22,6\% (12 responden) berada pada kategori cukup. 
b. Posttest Sesudah Pelaksanaan Penyuluhan Kesehatan

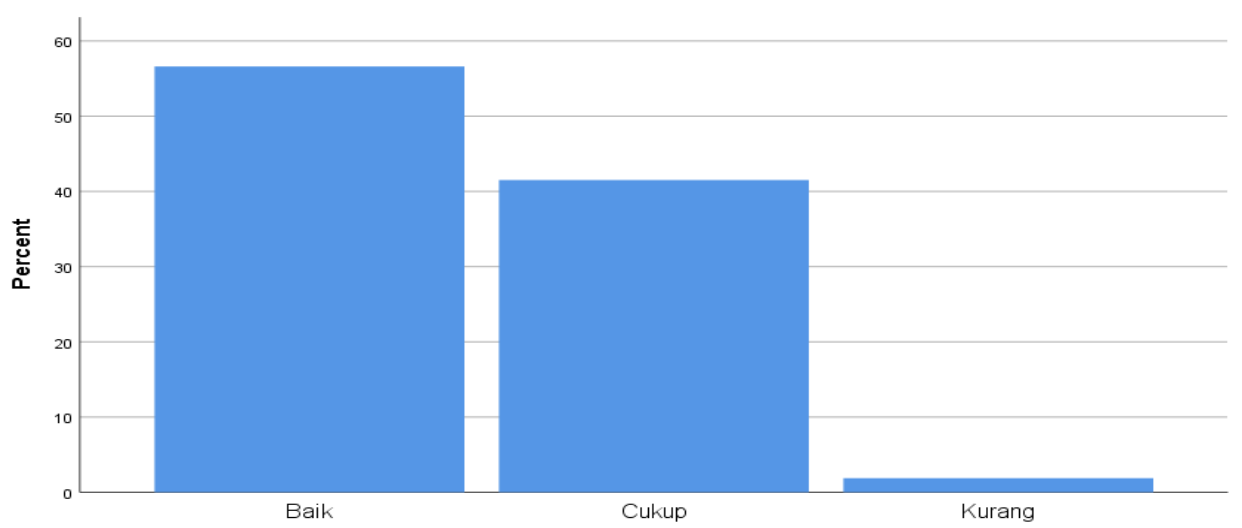

Diagram 2 Tingkat Pengetahuan Mahasiswa Profesi Ners Sesudah Penyuluhan Kesehatan Tentang APD

Tingkat pengetahuan responden setelah dilakukan penyuluhan kesehatan tentang penggunaan APD mayoritas dalam kategori baik yaitu sebesar 55,6\% (30 responden), $41,5 \%$ (22 responden) dalam kategori cukup, dan hanya 1,9\% (1responden) dalam kategori kurang.

Berikut gambar pelaksanaan kegiatan:

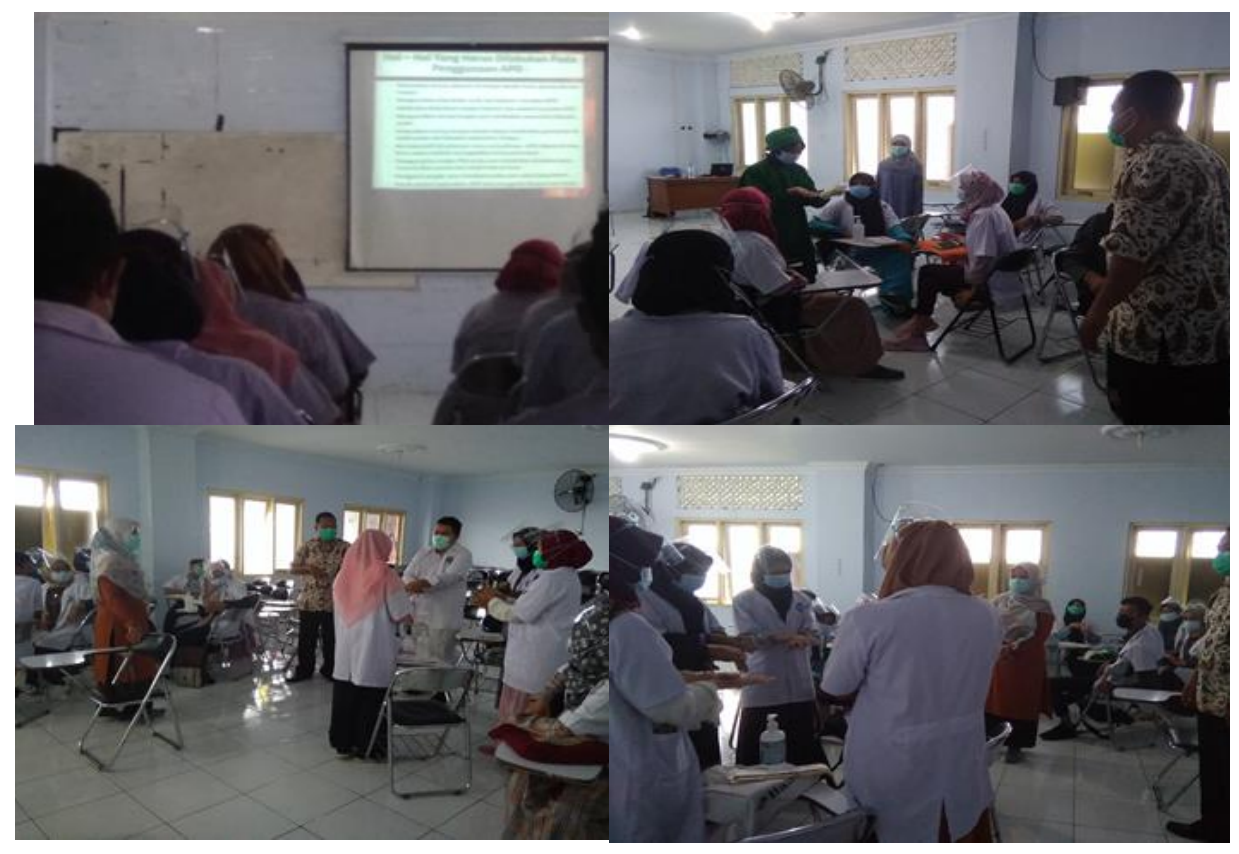

Gambar 4.1 Pelaksanaan Kegiatan Pengabdian Kepada Masyarakat

Penyuluhan kesehatan tentang penggunaan APD kepada mahasiswa profesi ners ini sangat penting karena dapat meningkatkan pengetahuan mahasiswa. Dengan meningkatnya tingkat pengetahuan mahasiswa profesi ners terkait dengan penggunaan APD diharapkan dapat mengubah sikap dan perilaku mahasiswa pada saat menempuh pendidikan profesi ners keperawatan di rumah sakit 


\section{KESIMPULAN}

Pelaksanaan kegiatan pengabdian masyarakat dalam bentuk penyuluhan kesehatan dengan sasaran mahasiswa profesi ners dilakukan untuk memberikan informasi terkait dengan penggunaan APD secara baik dan benar. Penyulukan kesehatan yang dilakukan terbukti dapat meningkatkan tingkat pengetahuan mahasiswa sehingga pada saat mahasiswa profesi ners praktik di rumah sakit dapat menerapkan penggunaan APD dengan tepat sebagai upaya pencegahan penularan covid-19.

\section{DAFTAR PUSTAKA}

Fadli., Safruddin., Ahmad, Andi Sastria., Sumbara., dan Baharuddin Rohandi. (2020). Faktor yang Mempengaruhi Kecemasan Pada Tenaga Kesehatan Dalam Upaya Pencegahan Covid-19. Jurnal Pendidikan Keperawatan Indonesia, 6 (1), 57-65

Guan, W. J., Chen, R. C. \& Zhong, N. S. (2020). Strategies for the Prevention and Management of Corona Virus Disease 2019. The European Respirator Journal, $55(4)$

Gupta, A., \& Kakkar, R. (2020). Managing a Covid-19 Patient at Different Health Care and Field Level Settings. Indian Journal of Community Health, 32 (2), 188-195

Kemenkes RI. (2020). Pedoman Pencegahan dan Pengendalian Corona Virus Disease (COVID-19). Jakarta : Direktorat Jenderal Pencegahan dan Pengendalian Penyakit

Nurbeti, Maftuhah., Prabowo, Eka Angga., Faris, Muhammad., dan Ismoyowati, Ratna. (2021). Hubungan Antara Tingkat Pengetahuan dengan Kepatuhan Staf Rumah Sakit dalam Penggunaan Alat Pelindung Diri Secara Rasional di Masa Pandemi Covid-19. Journal of Hospital Accreditation, 3 (2), 96-100

Persatuan Perawat Nasional Indonesia. (2020). Upaya PPNI Ajak Perawat Menjadi Tangguh Dalam Penanganan Pandemi Covid-19. Diakses dari https://ppniinna.org/index.php/public/information/news-detail/993 pada tanggal 24 November 2020

Sharma, S. K., Mudgal, S. K., Panda, P. K., Gupta, P., \& Agarwal, P. (2020). COVID-19: Guidance Outlines on Infection Prevention and Control for Health Care Workers. Indian Journal of Community Health, 32(1), 9-16

Urrahman, D., Endah, S., dan Aziz, A. (2021). Injury Perawat Pada Penggunaan Alat Pelindung Diri (APD) Dalam Pelayanan Covid-19. Jurnal Kesehatan Karya Husada, 9 (1), 91-103

WHO. (2020). General's opening remarks at the media briefing on COVID-19 - 11 March 2020". Retrieved from www. who.int

Zainaro, M. A., Andoko, A., \& Rahmawati, R. P. (2021). Hubungan Pengetahuan dan Sikap Terhadap Kejadian Covid-19 pada Masyarakat di Kelurahan Mulyojati Kota Metro. Malahayati Nursing Journal, 3(4), 517-528. 